\title{
Research Article \\ CULTURABLE ENDOPHYTIC BACTERIA FROM HALOTOLERANT Salvadora persica L.: SCREENING, ISOLATION AND PLANT GROWTH PROMOTING TRAITS
}

\author{
ABBAS H. ${ }^{*}$ AND PATEL R.M. ${ }^{2}$ \\ 'Department of Plant Molecular Biology and Biotechnology, Navsari Agricultural University, Navsari, 396450, Gujarat, India \\ ${ }^{2}$ ASPEE Shakilam Agricultural Biotechnology Institute, Athwa Farm, Surat, 395007, Navsari Agricultural University, Navsari, 396450, Gujarat, India \\ *Corresponding Author: Email-haidarabbas429@gmail.com
}

Received: March 07, 2018; Revised: March 16, 2018; Accepted: March 17, 2018; Published: March 30, 2018

\begin{abstract}
Twenty three endophytic bacterial isolates were isolated from the roots of Salvadora persica L. were characterized on the basis of various criteria such as morphology and biochemical characteristics, out of which six potential endophytes were selected based on their PGPR activity and identified by 16S rRNA gene sequence analysis as Citrobacter sp. A6 (KY587407), Pantoea agglomerans A10 (KY587408), Pseudomonas oryzihabitans A16 (KY963571), Serratia marcescens A20 (KY963572) Enterobacter aerogenes A23 (KY963573) and Bacillus sp. A26 (KY963574). Only Citrobacter sp. A6 (KY587407), Pantoea agglomerans A10 (KY587408) were able to produce IAA. Siderophore production was observed in only Enterobacter aerogenes A23. All isolates solubilized tricalcium phosphate except Bacillus sp. A26 and ACC deaminase production were observed in Citrobacter sp. A6 and Bacillus sp. A26. All isolates could withstand higher salt level (7 \% NaCl) whereas Serratia marcescens A20 tolerated up to $5 \%$ of $\mathrm{NaCl}$.
\end{abstract}

Key words- Salvadora persica, Halophyte, Endophyte, Plant growth promotion

Citation: Abbas H. and Patel R.M. (2018) Culturable Endophytic Bacteria from Halotolerant Salvadora persica L.: Screening, Isolation and Plant Growth Promoting Traits. International Journal of Microbiology Research, ISSN: 0975-5276 \& E-ISSN: 0975-9174, Volume 10, Issue 3, pp.1074-1077.

Copyright: Copyright@2018 Abbas H. and Patel R.M. This is an open-access article distributed under the terms of the Creative Commons Attribution License, which permits unrestricted use, distribution and reproduction in any medium, provided the original author and source are credited.

DOI: http://dx.doi.org/10.9735/0975-5276.10.3.1074-1077

\section{Introduction}

Salvadora persica $L$. of the family Salvadoraceae is an evergreen shrub, 4-6 $\mathrm{m}$ tall with a short trunk; also called as meswak, has white bark and smooth green leaves. It is one of the most commonly used medicinal plants for oral hygiene among global Muslim community [1]. Noumi and co-worker [2] reviewed the history, use of Meswak as an oral hygienic tool and the biological effects of its extract. Salvadora is the habitant of varieties of location ranging from mangroves, in saline land, swamps, thorn shrubs, deserts and flooded plains to near riverbanks where ground water level is high indicating their tolerance to a wide range of water, soil pH and salinity [3]. The Salvadora species have a number of proven pharmacological importance [4-7]. However, their medicinal values have been explored [8] but the efficiency of associative bacteria for plant growth promotion is not fully understood. Various bacteria collectively referred to as Plant Growth Promoting Rhizobacteria (PGPRs) colonize the rhizosphere of many plant species and some of which invades inner tissues without causing any symptoms [9], termed as endophytes, have beneficial effects on host plant growth, which is manifested physiologically as increased plant growth and reduced susceptibility to diseases [10]. These bacteria exhibit properties of phosphorus solubilization and siderophore production, which allow host plants to efficiently uptake phosphorusand iron-derived nutrients from the soil, respectively. In addition, certain endophytes may interfere with the biosynthesis of phytohormones, especially auxin and ethylene. IAA produced by endophytes increases total pool of hormone along with plant IAA [11].The direct association effect of bacterial indole acetic acid (IAA) production and modified root architecture of the host was clearly demonstrated between $A$. baselines and wheat [12]. Also, many microbes excrete 1-aminocyclopropane- 1-carboxylate (ACC) deaminase, which is encoded by the conserved acdS gene of endophytes and degrade the ethylene precursor ACC to ammonia and a-ketobutyrate, thereby reducing the level of ethylene which normally inhibits plant growth. Some of the other characteristics like phosphate solubilization [13] and $\mathrm{N}_{2}$ fixation [14] have been extensively studied for plant growth promotion. As mentioned, the modes of action of PGPR related factors are thus diverse and complex, but the mechanistic basis is still largely unknown, especially at the molecular level. The underground Salvadora persica roots favour growth of various microbial communities or endophytes, which modulates plant growth through the synthesis of biochemical and secondary metabolites to adjust plant against salt stress. The present investigation was undertaken to study the endophytic bacterial community of the Salvadora persica roots and their response to the salinity stress and plant growth promoting activities.
Materials and Methods
Isolation of endophytes
For isolation of endophytic bacterial isolates, roots of S. persica L. were collected from the coastal area of Dandi, South Gujarat, India. Fresh and healthy roots were washed to remove soil thoroughly under running tap water and dissected in small pieces followed by surface sterilization $\left(70 \% \mathrm{C}_{2} \mathrm{H}_{5} \mathrm{OH}, 3 \mathrm{~min}, 0.5 \% \mathrm{NaOCl}, 3 \mathrm{~min}\right.$ and $70 \% \mathrm{C}_{2} \mathrm{H}_{5} \mathrm{OH}, 30 \mathrm{sec}$ ) and rinsed thrice with sterile distilled water [15]. Surface sterilization efficiency was checked by inoculating surface sterilized root samples on nutrient agar plate, prior to inoculation of endophytic bacteria. The surface sterilized roots were air dried, further sliced into thin sections and placed aseptically over LB agar plate and incubated at $30^{\circ} \mathrm{C}$ for $2-4$ days in bacteriological incubator. The bacterial colonies surrounding root sections were picked and streaked on the fresh LB agar for the selection of single endophyte. Aseptic condition were maintained during whole isolation procedure. 


\section{Characterization of bacterial isolates}

Endophytic bacterial isolates were characterized on the basis of biochemical characteristics by Bergey's manual of determinative bacteriology [16] and molecular phylogeny by 16S rRNA gene sequencing. Genomic DNA was isolated using GeneiPure ${ }^{T M}$ bacterial DNA purification kit (Bangaluru, India) following the manufacture's protocol. Universal eubacterial primers $27 \mathrm{~F}-5^{\prime}$ AGAGTTTGATCMTGGCTCAG 3' and 1492R- 5' CGGTTACCTTGTTACGACTT $3^{\prime}$ were used to amplify approximately 1500 bp region of $16 \mathrm{~S}$ rRNAgene using a thermal cycler (Eppendorf, Germany). Amplified products were resolved by agarose-gel electrophoresis (1.5\%), and visualized using a gel documentation system (Bio Rad, USA). Theamplicons were purified using GeneiPure ${ }^{T M}$ quick PCR purification kit and quantified at $260 \mathrm{~nm}$ using a Nanodrop (Thermo scientific). The purified partial 16S rDNA amplicons were sequenced in an Applied Biosystems 3130 Genetic Analyzer (Applied Biosystems, CA, and USA).

\section{Analysis of $16 \mathrm{~S}$ rDNA sequences}

The partial sequences of nucleotides were compared with available sequences from NCBI databases and sequences showing $>98 \%$ similarity was retrieved by Nucleotide Basic Local Alignment Search Tool (BLAST N) program available at the National Center for Biotechnology Information (NCBI) BLAST server (www.ncbi.nlm.nih.gov/BLAST).

\section{PGP traits analysis \\ Production of IAA}

Bacteria were cultivated at $28 \pm 2^{\circ} \mathrm{C}$ for $48 \mathrm{~h}$ in LB broth supplemented with 100 $400 \mu \mathrm{g} \mathrm{ml}{ }^{-1}$ of L-tryptophan and harvested through centrifugation (8000 rpm, 10 $\mathrm{min})$. Supernatant (2 $\mathrm{ml}$ ) was mixed with 2 drops of orthophospheric acid and $4 \mathrm{ml}$ of the Salkowski reagent $\left(50 \mathrm{ml}, 35 \%\right.$ of perchloric acid, $1 \mathrm{ml} 0.5 \mathrm{M} \mathrm{FeCl}_{3}$ solution) [17]. Production of IAA was confirmed by the development of pink colour.

\section{Phosphate solubilization}

The bacterial strains were inoculated on the Pikovskaya medium containing tricalcium phosphate on agar plate and incubated at $28 \pm 2{ }^{\circ} \mathrm{C}$ for 2-3 days [18]. Development of clear halo zone around the strains exhibited their positive phosphate solubilization activity.

\section{Siderophore production}

The cultured bacterial strains were spotted on the Chromeazurol S agar plate [19]. Development of yellow orange hallow zone around the bacterial spot has been considered as positive indication for Siderophore production.

\section{ACC deaminase production}

The isolates were point inoculated on DF salt minimal medium containing ACC as sole nitrogen source [20]. Briefly, the composition of salt minimal media containing ACC as sole nitrogen source in $\mathrm{g} \mathrm{L}^{-1}$ is as follows, $\mathrm{KH}_{2} \mathrm{PO}_{4}, 1.36$; $\mathrm{Na}_{2} \mathrm{HPO}_{4}, 2.13$; $\mathrm{MgSO}_{4} .7 \mathrm{H}_{2} \mathrm{O}, 0.2 ; \mathrm{CaCl}_{2} .2 \mathrm{H}_{2} \mathrm{O}, 0.7 ; \mathrm{FeSO}_{4} .7 \mathrm{H}_{2} \mathrm{O}, 0.2 ; \mathrm{CuSO}_{4} .5 \mathrm{H}_{2} \mathrm{O}, 0.04 ;$ $\mathrm{MnSO}_{4} . \mathrm{H}_{2} \mathrm{O}, \quad 0.02 ; \mathrm{ZnSO}_{4} .7 \mathrm{H}_{2} \mathrm{O}, \quad 0.02 ; \mathrm{H}_{3} \mathrm{BO}_{3}, 0.003 ; \mathrm{CoCl}_{2} .6 \mathrm{H}_{2} \mathrm{O}, \quad 0.007 ;$ $\mathrm{Na}_{2} \mathrm{MoO}_{4} .2 \mathrm{H}_{2} \mathrm{O}, 0.004$; Substrate ACC, $5 \mathrm{mM}$; Glucose, $1.0 \%$ dissolved in 1000 $\mathrm{mL}$ of distilled water. Growth on these plates shows positive result for ACC deaminase production.

\section{Salt tolerance}

To check salt tolerance efficiency endophytes were streaked on LB media containing different concentration of $\mathrm{NaCl}(4-9 \%)$ and incubated at $28 \pm 2{ }^{\circ} \mathrm{C}$ to check the salt tolerance of the isolates [21].

\section{Results}

A total of 23 different bacterial clones were isolated from the sliced Salvadora persica roots while no bacteria were observed near the surface sterilized root samples. Out of 21 clones 6 clones were identified based on their good PGPR activities by16S rRNA gene sequence as Citrobacter sp. A6 (KY587407), Pantoea agglomerans A10 (KY587408), Pseudomonas oryzihabitans A16 (KY963571), Serratia marcescens A20 (KY963572) Enterobacter aerogenes A23 (KY963573) and Bacillus sp. A26 (KY963574) which are belonged to y Proteobacteria (Pantoea, Serratia, Enterobacter, Citrobacter) and Firmicutes (Bacillus) [Table-1] and [Fig-1].

Table-1 Closest relative of the isolated strains as revealed by 16 S rRNA gene sequencing

\begin{tabular}{|c|l|c|c|l|c|c|}
\hline $\begin{array}{c}\text { Sr } \\
\text { no. }\end{array}$ & Source & Strain & $\begin{array}{c}\text { Accession } \\
\text { no. }\end{array}$ & $\begin{array}{c}\text { Nearest } \\
\text { Phylogenetic } \\
\text { Neighbour }\end{array}$ & $\begin{array}{c}\text { Similarity } \\
(\%)\end{array}$ & $\begin{array}{c}\text { E- } \\
\text { value }\end{array}$ \\
\hline 1 & $\begin{array}{l}\text { Salvadora } \\
\text { persica }\end{array}$ & A6 & KY587407 & $\begin{array}{l}\text { Citrobacter sp. } \\
\text { BAN69 }\end{array}$ & $99 \%$ & 0 \\
\hline 2 & $\begin{array}{l}\text { Salvadora } \\
\text { persica }\end{array}$ & A10 & KY587408 & $\begin{array}{l}\text { Pantoea } \\
\text { agglomerans }\end{array}$ & $92 \%$ & 0 \\
\hline 3 & $\begin{array}{l}\text { Salvadora } \\
\text { persica }\end{array}$ & A16 & KY963571 & $\begin{array}{l}\text { Pseudomonas } \\
\text { oryzihabitans } \\
\text { strain 7 }\end{array}$ & $98 \%$ & 0 \\
\hline 4 & $\begin{array}{l}\text { Salvadora } \\
\text { persica }\end{array}$ & A20 & KY963572 & $\begin{array}{l}\text { Serratia } \\
\text { marcescens } \\
\text { strain JW-QS2 }\end{array}$ & $100 \%$ & 0 \\
\hline 5 & $\begin{array}{l}\text { Salvadora } \\
\text { persica }\end{array}$ & A23 & KY963573 & $\begin{array}{l}\text { Enterobacter } \\
\text { aerogenes 8a }\end{array}$ & $99 \%$ & 0 \\
\hline 6 & $\begin{array}{l}\text { Salvadora } \\
\text { persica }\end{array}$ & A26 & KY963574 & $\begin{array}{l}\text { Bacillus sp. } \\
\text { NCCP-975 }\end{array}$ & $99 \%$ & 0 \\
\hline
\end{tabular}

\section{PGP traits}

Only Citrobacter sp. A6 (KY587407) and Pantoea agglomerans A10 (KY587408) endophytic bacterial strains produced IAA on supplementation of $400 \mu \mathrm{g} \mathrm{ml}-1 \mathrm{~L}$ tryptophan [Fig-2]. Siderophore production was observed in only Enterobacter aerogenes A23. All isolates solubilized phosphate except Bacillus sp. A26 and ACC Deaminase production were observed in Citrobacter sp. A6 and Bacillus sp. A26. All isolates could withstand higher salt level $(7 \% \mathrm{NaCl})$ whereas Serratia marcescens $\mathrm{A} 20$ tolerated up to $5 \%$ of $\mathrm{NaCl}$ [Table-2].

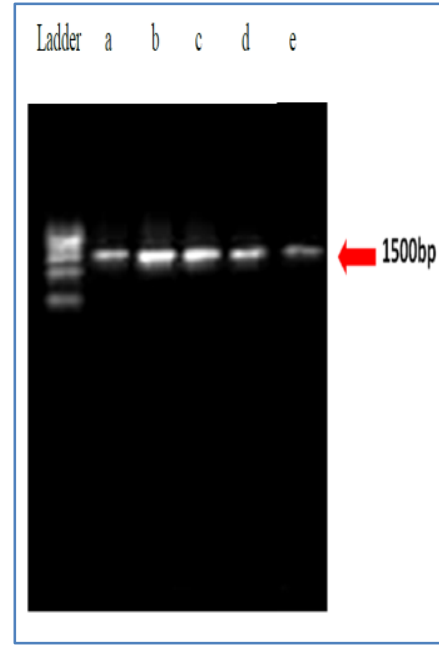

Fig-1 IAA production assay of bacterial endophyte.a) $A 6$, b) A10, c) A16, d) A20 and e) A23.

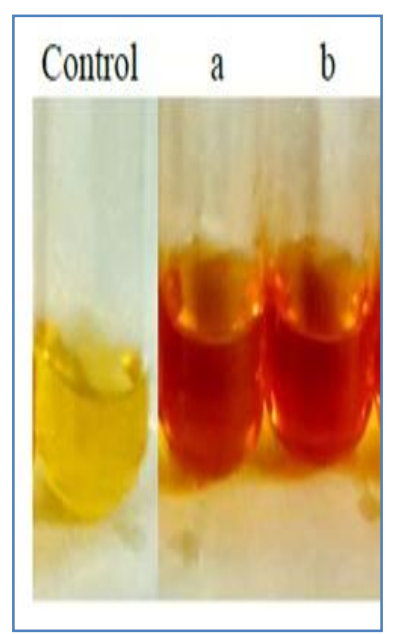

Fig-2 IAA production assay of bacterial endophytes. a) $A 6, b$ ) A10.

\section{Discussion}

The S. persica roots were colonized by diverse endophytic bacteria. These endophytic bacterial isolates belonged to four different genera Bacillus, Pantoea, Serratia and Enterobacter. These strains previously reported as endophytes in different plant species like Bacillus aerius from Spharanthus indicus [22], Pantoea agglomerans from citrus [23], Serratia nematodiphila from Solanum nigrum [24], Enterobacter sp. from Curcuma longa L [25]. Many endophytic microorganisms have the potential to produce IAA. This may be a reason for the increased growth promotion of some plants when the plant is colonized with endophytes as bacterial IAA increases total pool of IAA along with plants IAA [26]. IAA is the most common plant hormone, which stimulate the growth and reproduction in plants [27] and is also involved in cell enlargement and division, tissue differentiation, physiological processes [28]. 
Abbas H. and Patel R.M.,

Table-2 Biochemical and plant growth promoting activity (intensity wise) of endophytes

\begin{tabular}{|c|c|c|c|c|c|c|c|c|c|}
\hline Sr. no. & Isolates & $1.1 \mathrm{M}$ & $\begin{array}{c}\text { Amylase } \\
\text { Production }\end{array}$ & $\begin{array}{c}\text { Cellulase } \\
\text { Production }\end{array}$ & $\begin{array}{c}\text { Protease } \\
\text { Production }\end{array}$ & $\begin{array}{l}\text { Siderophore } \\
\text { Production }\end{array}$ & $\begin{array}{c}\text { ACC Deaminase } \\
\text { Production }\end{array}$ & $\begin{array}{l}\text { Phosphatase } \\
\text { Production }\end{array}$ & $\begin{array}{c}\text { IAA } \\
\text { Production }\end{array}$ \\
\hline 1 & A4 & + & & & & + & & ++ & \\
\hline 2 & A5 & + & & & & + & & t+t+ & \\
\hline 3 & $A 6$ & + & + & ++ & ++ & & + & & +++ \\
\hline 4 & A10 & + & & +++ & & & & +++ & +++ \\
\hline 5 & A11 & + & & & & & & ++++ & \\
\hline 6 & A14 & & & & + & t+ & & +++ & \\
\hline 7 & $\mathrm{~A} 16$ & + & & & & & & + & +++ \\
\hline 8 & A18 & + & & & ++ & ++ & & $+t$ & \\
\hline 9 & A19 & & & & & & & ++++ & \\
\hline 10 & A20 & + & & + & + & & & + & + \\
\hline 11 & A21 & + & & + & & & & & + \\
\hline 12 & A23 & + & & & & +++ & & t+t+ & \\
\hline 13 & A24 & & & & & + & + & ++++ & +++ \\
\hline 14 & A26 & + & + & +++ & ++ & & + & & \\
\hline 15 & A28 & + & & & & ++ & & +++ & \\
\hline 16 & A29 & + & & & & & + & ++ & +++ \\
\hline 17 & A32 & + & & & & & & +++ & \\
\hline 18 & A33 & + & & & & & & + & \\
\hline 19 & A35 & & & ++ & & & & ++ & \\
\hline 20 & A37 & + & & ++ & & & & & + \\
\hline 21 & A39 & & + & +++ & & & & & + \\
\hline 22 & A41 & + & & & & & + & & +++ \\
\hline 23 & A42 & & & & & & & ++++ & +++ \\
\hline
\end{tabular}

For the microbial synthesis of IAA in tryptophan dependent route, tryptophan is used as the precursor. The amount of IAA produced by bacteria play important role in plant-microbe interaction [29]. The modulation of plant growths takes place by optimal IAA concentration range. In the study [30] it is found that inoculation of IAA producing bacteria Pseudomonas thivervalensis at the amount $10^{5} \mathrm{CFU} \mathrm{m} \mathrm{ll}^{-1}$ in Arabidopsis resulting reproducible morphological changes but the amount of $10^{6}$ CFU ml-1 inoculants inhibit the plant growth. The ability of the production of IAA by different species of Pseudomonas was reported by many authors [31]. During the plant growth promotion trait analysis, only Citrobacter sp. A6 (KY587407) and Pantoea agglomerans A10 (KY587408) strains produced significant amount of IAA. The extent of production was found maximum in case of Citrobacter sp. A6 in the presence of tryptophan. IAA produced by bacteria increases pool of total IAA along with plant IAA and affects plants by diverse ways from pathogenesis to phyto-stimulation. Siderophore production by the bacterial strain is one of the biocontrol mechanisms. The iron-chelation by bacteria makes them better competitors for the available iron and in this way, prevents growth of the pathogenic microorganisms. Different species of Bacillus have been reported to have the ability to produce of siderophores [32,33]. Many reports reveal the ability of both gram negative bacterial isolates (Pseudomonas sp.) and bacterial genera of Bacillus and Rhodococcus that belongs to the gram positive group with the capability to produce siderophores [34]. In this study siderophore production was observed in Enterobacter aerogenes A23. Plant growth promoting bacteria solubilize insoluble phosphates to make them available to enhance crop productivity. When applied to seed, plant surfaces or soil, PSM colonizes the interior of the plant (endophytes) and facilitate growth by providing phosphate to growing plants [35]. All isolates except Bacillus sp. A26 solubilized phosphate. The endophytic bacterial isolates reside and multiply in the plants where the environment contains relatively high ionic strength which successively tolerated both the biotic and abiotic factors. Previously many authors reported the endophytic strain which successively tolerated the high salt concentration [36-39]. In this study the endophytic isolates were able to grown differentially at different salt levels. In a previous study, Pseudomonas sp. tolerated up to $4 \% \mathrm{NaCl}$, while Bacillus sp. $2 \% \mathrm{NaCl}$ [40]. The endophytic bacterial strains of Momordica charentia showed tolerance to $4-10 \% \mathrm{NaCl}$ [41]. ACC, the immediate precursor of $\mathrm{C}_{2} \mathrm{H}_{4}$ (ethylene), mainly exuded by plant and taken up by the bacteria and hydrolysed by ACC deaminase results in $\mathrm{NH}_{3}$ and a-ketobutyrate formation [42], and hence, it strongly alleviates the stress induced by ethylene-mediated impact on plants by lowering the ethylene levels in plants [43]. This decrease in the levels of ACC and ethylene may prevent the ethylene-mediated plant growth inhibition. Endophytic microbes with these capabilities residing inside the host plants can benefit the host by reducing the stress and increasing the plant growth [44]. Alizadeh [45] has explained the application of the ACC deaminase which has been synthesised by different genera of Pseudomonas in increasing the senescence of the plants. The bacteria utilize the $\mathrm{NH}_{3}$ so evolved from ACC as a source of $\mathrm{N}$ and thereby restrict the accumulation of ethylene within the plant, which otherwise inhibits plant growth [46]. ACC deaminase production was reported by Citrobacter sp. A6 and Bacillus sp. A26.

\section{Conclusion:}

The diverse endophytic bacterial strains (A6, A10, A16, A20, A23 and A26) were isolated from the root of $S$. persica. They harbour PGP traits of variable degrees to establish symbiotic relationship with the host. Out of six, two strains produced IAA; five solubilized phosphate, two produced ACC deaminase, one produced siderophore and five tolerated high salt $(7 \% \mathrm{NaCl})$ concentration during salinity tolerance. Further, these isolates need to be analyzed for beneficial effects on plants. Also, change in metabolites of treated plants need to be compared with control plants which might reveal exact mechanism of plant growth promotion.

Application of research: Identification of Plant Growth Promoting Bacterial endophytes help to investigate the possible association of these bacteria with crops and can combat adverse biotic and abiotic stresses of environment.

Research Category: Microbiology, Plant- Microbe interaction

\section{Abbreviations:}

PGP: Plant Growth promotion

ACC: 1- Amino Cyclopropane 1- Carboxylate

IAA: Indole Acetic Acid

$\mathrm{NaCl}$ : Sodium Chloride

LB: Luria Bertani

$\mathrm{NaOCl}$ Sodium Hypochlorite

Acknowledgement / Funding: Author thankful to Navsari Agricultural University, Navsari, 396450, Gujarat

\section{*Major Advisor: Dr. R.M. Patel}

University: Navsari Agricultural University, Navsari, 396450, Gujarat

Research project name or number: $\mathrm{PhD}$ Thesis 


\section{Author Contributions: All author equally contributed}

Author statement: All authors read, reviewed, agree and approved the final manuscript

\section{Conflict of Interest: None declared}

Ethical approval: This article does not contain any studies with human participants or animals performed by any of the authors.

\section{References}

[1] Sher H., Al-Yemeni M. N., Yahya S. M. and Arif H. S. (2010) J Med Plants Res, 4, 1209-1215.

[2] Noumi E., Snoussi M., Hajlaoui H., Valentin E. and Bakhrouf A. (2010) Eur J Clin Microbiol Infect Dis, 29, 81-88.

[3] Zodape S. T. and IndusekharV. K. (1997) J. Sci. Indust. Res., 56, 657-661

[4] Almas K. (2002) J. Contemp. Dent. Pract., 3, 27-35.

[5] Almas K. and Al-Zeid, Z. (2004) J. Contemp. Dent. Pract., 1, 105-114.

[6] Darmani H., Nusary T. and Al-Hiyasat A. S. (2006) Int.Dent. Hygiene, 4, 6266.

[7] Chelli-Chentouf N., ATT Medddah C., Mullie A. andMeddah B. (2012) J. Ethnopharmacol., 144, 57-66.

[8] Essaidi I., Brahmi Z., Snoussi A., Koubaier H. B. H., Casabianca H., Abe N. and Bouzouita N. (2013) Food Control, 32(1), 125-133.

[9] Wilson D. (1995) Oikos, 73 (2), 274-276.

[10] Bulgarelli D., Schlaeppi K., Spaepen S., Ver Loren van Themaat E. and Schulze-Lefert P. (2013) Annu. Rev. Plant Biol., 64, 807-838.

[11] Lee S., Flores-ncarnacion M., Contreras-Zentella M., Garcia-Flores L., Escamilla J. E. and Kennedy C. (2004) J Bacteriol, 186,5384-5391.

[12] Spaepen S., Vanderleyden J., and Remans R. (2007) Fems. Microbiol. Rev., 31, 425-448.

[13] Wakelin S. (2004) Biol Fertil Soils, 40,36-43.

[14] Compant S., Reiter B., Sessitsch A., Nowak J., Cle'ment C. and Ait Barka E. (2005) Appl Environ Microbiol, 71,1685-1693.

[15] Sun J., Guo L., Zang W., Ping W. and Chi D. (2008) Science in China Series C, Life Sciences, 51(8), 751-759.

[16] Kumar V., Kumar A., Pandey K. D., and Roy B. K. (2015) Annals of microbiology, 65(3), 1391-1399.

[17] Bric J. M., Bostock R. M. and Silverstone S. E. (1991) Appl Environ Microbiol, 57(2),535-538.

[18] Pikovskaya R. I. (1948) Microbiology, 17, 362-370.

[19] Schwyn B. and Neilands J. B. (1987) Anal.Biochem., 160, 47-56.

[20] Dworkin M. and Foster J. (1958) J. Bacteriol., 75, 592-601.

[21] Pirhadi M., Enayatizamir N., Motamedi H. and Sorkheh K. (2016) Bioscience Biotechnology Research Communications, 9(3),530-538.

[22] Arora S., Patel P. N., Vanza M. J. and Rao G.G. (2014) African Journal of Microbiology Research, 8(17),1779-1788.

[23] Andreote F. D., Rossetto P. B., Souza L. C., Marcon J., Maccheroni W. Azevedo J. L. and AraujoW. L. (2008) Journal of basic microbiology, 48(5), 338.

[24] Chen L., Luo S., Xiao X., Guo H., Chen J., Wan Y. and Liu C. (2010) Applied soil ecology, 46(3), 383-389.

[25] Kumar A., Singh R., Yadav A., Giri D. D., Singh P. K. and Pandey K. D.(2016) Biotech, 6(1), 1-8.

[26] Shi Y., Lou K. and Li C. (2009) Afr J Biotechnol, 8,835-840

[27] Taghavi S., Garafola C., Monchy S., Newman L., Hoffman A., Weyens N. and van der Lelie D. (2009) Applied and Environmental Microbiology, 75(3), 748-757.

[28] Woodward A. W. and Bartel B. (2005) Ann Bot (London), 95,707-735.

[29] Xie H., Pasternak J. J. and Glick B. R. (1996) Current Microbiology, 32(2), 67-71.

[30] Persello-Cartieaux F., Nussaume L., and Robaglia C. (2003) Plant, Cell and Environment, 26(2), 189-199.
[31] Karnwal A. (2009) J Plant Pathol, 91(1),61-63

[32] Gardner R. A., Kinkade R., Wang C. and Phanstiel O. (2004) J Org Chem., 69,3530-3537.

[33] Wilson M. K., Abergel R. J., Arceneaux J. E., Raymond K. N. and Byers B. R. (2010) Biometals, 23,129-134.

[34] Tian F., Ding Y., Zhu H., Yao L. and Du B. (2009) Brazilian J Microbiol, 40, 276-284.

[35] Khan M. S., Zaidi A. and Wani P. A. (2006) Agron Sustain Dev, 27,29-43.

[36] Hallmann J., Quadt-Hallmann A., Mahaffee W. F. and Kloepper J. W. (1997a) Can J Microbiol, 43(10),895-914.

[37] Hallmann J., Quadt-Hallmann A., Rodriguez-Kabana R. and Kloepper J. W. (1997b) Soil Biol Biochem 30, 925-937.

[38] Lopez B. R., Bashan Y., and Bacilio M. (2011) Archives of microbiology, 193(7), 527-541.

[39] Kumar V., Kumar A., Pandey K. D., and Roy B. K. (2015) Annals of microbiology, 65(3), 1391-1399.

[40] Rashid S., Charles T. C. and Glick B. R. (2012) Applied soil ecology, 61, 217-224.

[41] Singh R., Kumar A., Singh M. and Pandey K. D. (2013) Effect of salt stresson endophytic bacteria isolated from root of Momordica charantia. In, Indian Society of Vegetable Science, National Symposium on Abiotic and Biotic Stress Management inVegetable Crops.

[42] Safronova V. I., Stepanok V. V., Engqvist G. L., Alekseyev Y. V. and Belimov A. A. (2006) Biology and Fertility of Soils, 42(3), 267-272.

[43] Glick B. R., Todorovic B., Czarny J., Cheng Z., Duan J. and McConkey B. (2007) Critical Reviews in Plant Sciences, 26(5-6), 227-242.

[44] Hardoim P. R., van Overbeek L. S. and van Elsas J. D. (2008) Trends Microbiol., 16,463-471.

[45] Alizadeh O., Sharafzadeh S. and Firoozabadi A. H. (2012) Asian J Plant Sci., 11,1-8

[46] Belimov A. A., Safronova V. I. and Mimura T. (2002) Canadian Journal of Microbiology, 48(3), 189-199. 